\title{
Gonadal maturity of Crassostrea corteziensis cultivated in the Gulf of California
}

\author{
Andrés Martín Góngora-Gómez ${ }^{1}$, Carlos Humberto Sepúlveda ${ }^{1}$, Héctor Alejandro Verdugo Escobar ${ }^{1}$ \\ Osvaldo Astorga Castro ${ }^{3}$, Hervey Rodríguez-González ${ }^{1}$, Ana Laura Domínguez-Orozco ${ }^{2}$ \\ Juan Antonio Hernández-Sepúlveda ${ }^{2} \&$ Manuel García-Ulloa ${ }^{1}$ \\ ${ }^{1}$ Instituto Politécnico Nacional, Centro Interdisciplinario de Investigación para el Desarrollo Integral \\ Regional (CIIDIR-Unidad Sinaloa), Departamento de Acuacultura, Guasave, Sinaloa, México \\ ${ }^{2}$ Instituto Politécnico Nacional, Centro Interdisciplinario de Investigación para el Desarrollo Integral \\ Regional (CIIDIR-Unidad Sinaloa), Departamento de Medio Ambiente, Guasave, Sinaloa, México \\ ${ }^{3}$ Universidad Autónoma de Occidente, Licenciatura en Biología, Unidad Guasave \\ Guasave, Sinaloa, México \\ Corresponding author: Manuel García-Ulloa (turbotuag@hotmail.com)
}

\begin{abstract}
The gonadal maturation of the pleasure oyster Crassostrea corteziensis during four cultivation cycles (November 2004-June 2005, N4J5; August 2014-February 2016, A14F16; September 2015-December 2016, S15D16; September 2016-August 2017, S16A17) was studied in the southeastern Gulf of California, Mexico. Although C. corteziensis exhibited the typical reproductive phases (undifferentiated or resting, initial gametogenesis, advanced gametogenesis, maturity, spawning and post-spawning), the intensity of reproduction and the timing of the onset of the different phases of gonadal development varied in each cultivation cycle. Reproductive peaks were observed in different months (N4J5 in May, A14F16 in July, S15D16 in May and S16A17 in June) during spring and summer. Spawning correlated with temperature in the N4J5 and A14F16 cultivation cycles but it showed no correlation with chlorophyll-a concentration in any of the cultivation cycles. C. corteziensis presented an opportunistic continuous reproductive strategy with spawning occurring during several months of the year. The modification of the species' reproduction pattern could contribute to the natural settlement of larvae, increasing the natural production of this native oyster resource in the southeast of the Gulf of California, where it has been fished intensively.
\end{abstract}

Keywords: Crassostrea corteziensis; Cortez oyster; reproduction; gametogenesis; spawning; farming; Sinaloa

\section{INTRODUCTION}

Studies on reproduction in wild populations of commercially important bivalve mollusks offer valuable information for their management, conservation, and exploitation (Goslin, 2015). When bivalves are cultivated, indicators such as gonad formation and growth help in determining the appropriate time for harvesting (Aníbal et al., 2011). Gonadal development phases are frequently observed throughout the cultivation cycle in bivalve species (Arellano-Martínez et al., 2011; Gomes et al., 2014; Ángel-Dapa et al., 2015). Nevertheless, bivalve reproduction is strongly affected by exogenous factors such as environmental variables that are affected by global warming (Lawrence
\& Soame, 2004). High temperature (Beukema et al., 2009), low salinity (Peteiro et al., 2018), and high levels of toxic compounds (Guzmán-García et al., 2009) disrupt several metabolic pathways involved in bivalve reproduction. Different reproductive responses can be observed not only between species and localities but also between individuals of the same species at the same site (Hernández-Otero et al., 2014).

The pleasure or Cortez oyster (Crassostrea corteziensis) is a bivalve species cultivated semiintensively in northwest Mexico (Chávez-Villalba et al., 2005). Endemic to this region, C. corteziensis is highly valued for consumption and represents an important resource for the oyster industry. Its reproduc-

Corresponding editor: Cesar Lodeiros 
tive cycle has been reported for natural (RodríguezJaramillo et al., 2008; Mena-Alcántar et al., 2017) and cultivated populations (Chávez-Villalba et al., 2008; Mazón-Suástegui et al., 2011) from different sites along the northwestern coast of the Mexican Pacific, including the Gulf of California. C. corteziensis has an opportunistic reproductive strategy; they focus on nutrient-rich sites where they acquire energy through nutrient consumption, particularly lipids and carbohydrates (Racotta et al., 2008). This strategy allows the pleasure oyster to be reproductively active almost yearround (Hurtado et al., 2012); that is, as a sub-tropical oyster, its annual reproductive pattern is characterized by an extended reproductive period and several partial spawns (Rodríguez-Jaramillo et al., 2017) that lead to variations in reproductive responses.

To our understanding, there is only one study on the gonadal development of a natural population of the pleasure oyster in Sinaloa (Ceuta Lagoon System), Mexico, carried out by Rodríguez-Jaramillo et al. (2008). Since 2004 researchers at the Laboratorio de Malacología at the Centro Interdisciplinario de Investigación para el Desarrollo Integral Regional (CIIDIR)-Unidad Sinaloa, a branch of the Instituto Politécnico Nacional, have been working on obtaining data on gonadal maturity of $C$. corteziensis cultivated in the San Ignacio-Navachiste-Macapule Lagoon System (Sinaloa, Mexico). The present study aimed to analyze the relationship between environmental parameters with gonadal development of the pleasure oyster of four cultivation cycles (from 2004 to 2017) at a farm located in the Macapule Lagoon, in Sinaloa, Mexico and contrasted with previous studies (see references) carried out in other locations in northwestern Mexico. Besides, factors such as initial size, seed origin, and seeding month are discussed.

\section{MATERIALS AND METHODS}

\section{Study site and oysters}

The cultivation cycles (Nov 2004-Jun 2005, Aug 2014Feb 2016, Sep 2015-Dec 2016, and Sep 2016-Aug 2017, coded as N4J5, A14F16, S15D16, and S16A17, respectively) were carried out at an oyster farm located in the La Piedra estuary $\left(25^{\circ} 21^{\prime}-25^{\circ} 24^{\prime} \mathrm{N}, 108^{\circ} 30^{\prime}\right.$ $108^{\circ} 45^{\prime} \mathrm{W}$ ), part of the mangrove system in the Macapule Lagoon (Sinaloa, Mexico). The suspended long-line culture system was used in all these studies (Rodríguez-Quiroz et al., 2016). Oyster seeds were produced under laboratory conditions: N4J5 at Centro de Investigaciones Biológicas del Noroeste (CIBNOR), A14F16 and S16A17 at Centro Reproductor de Especies Marinas del Estado de Sonora (CREMES), and S15D16 at Instituto Sinaloense de Acuacultura y
Pesca (ISAPESCA) and planted after summer (as routinely done in the region, Rodríguez-Quiroz et al., 2016) and according to the capacity and production availability of each laboratory. All the oyster seed groups (3-4 mm in height shell) were transported to the cultivation site, acclimated following Gallo-García et al. (2001), deposited in plastic mesh sacks ( $2 \mathrm{~mm}$ mesh opening), and finally, the sacks were placed onto Nestier ${ }^{\mathrm{TM}}$ type culture baskets. The initial density (500 oysters per tray) was thinned to 80 oysters per tray after an initial period (45 days) of field nursery. Oyster seeds reached a juvenile minimum size of $9-10 \mathrm{~mm}$ in width, so they could be placed directly in the Nestier ${ }^{\mathrm{TM}}$ type culture baskets, which have a hole opening $(5 \mathrm{~mm})$ for water exchange. Cleaning and maintenance of trays, ropes, and sacks occurred every 15 days. Table 1 shows the initial conditions of the cultivation cycles.

\section{Environmental parameters}

Water temperature, dissolved oxygen (YSY55/12FT Oxymeter, Ohio, USA), salinity (ATAGO, S/Mill refractometer), and pH (Hanna, HI 8314 pHmeter, USA) were recorded monthly during each cultivation cycle. At the same time, depth and transparency were sampled with a Secchi disk. A PVC tube $(5 \mathrm{~cm}$ diameter and $2 \mathrm{~L}$ capacity) fitted with an end plunger seal was used to sample the water column to determine the total suspended solids (TSS), particulate organic matter (POM), and chlorophyll- $a$ concentration (Chl- $a$ ). The gravimetric technique (APHA, 1995) was used to determine the TSS and POM, while the spectrophotometric method (Strickland \& Parsons, 1972) was performed to determine the Chl- $a$.

\section{Oyster measurements, survival, and condition index}

A total of 50 oysters were taken from the culture system to record the height, thickness, width, and total weight measurements each month. Survival, expressed as a percentage of the initial oyster density, was calculated by separating and counting the empty shells at each sampling. The dry weight of the shells and tissues of 30 oysters $\left(24 \mathrm{~h}\right.$ at $\left.100^{\circ} \mathrm{C}\right)$ was used to calculate the condition index $(\mathrm{CI})$ defined by Chávez-Villalba et al. (2008): CI = P1 × $1000 / \mathrm{P} 2$, where P1 = soft tissue dry weight $(\mathrm{g})$, and $\mathrm{P} 2=$ shell dry weight $(\mathrm{g})$.

\section{Histological analysis}

The visceral mass (gonad included) of each oyster was dissected, fixed in Davidson's solution for $24 \mathrm{~h}$, dehydrated through a sequence of alcohol, cleared with Hemo-De ${ }^{\circledR}$, and embedded in Paraplast-Xtra ${ }^{\circledR}$ following Humason (1979). Sections $4 \mu \mathrm{m}$ thick were cut using a rotary microtome, placed on a slide, stained with Harris haematoxylin-eosin, and examined under a 
Table 1. Initial characteristics of the rearing cycles of Crassostrea corteziensis cultivated at La Piedra Estuary, Sinaloa, Mexico. CIBNOR: Centro de Investigaciones Biológicas del Noroeste; CREMES: Centro Reproductor de Especies Marinas del Estado de Sonora, ISAPESCA: Instituto Sinaloense de Acuacultura y Pesca. *Different superscripts in the initial shell length denote differences significantly $(P \leq 0.05)$. N4J5: Nov 2004-Jun 2005, A14F16: Aug 2014-Feb 2016, S15D16: Sep 2015-Dec, S16A17: Sep 2016-Aug 2017.

\begin{tabular}{lcccc}
\hline Source of seed & $\begin{array}{c}\text { Amount of } \\
\text { seed stock }\end{array}$ & $\begin{array}{c}\text { Initial shell } \\
\text { length }(\mathrm{mm})\end{array}$ & $\begin{array}{c}\text { Cultivation } \\
\text { time (months) }\end{array}$ & $\begin{array}{c}\text { Month } \\
\text { of sowing }\end{array}$ \\
\hline N4J5 CIBNOR & 5000 & $4.13 \pm 0.67^{\mathrm{c}^{*}}$ & 7 & November \\
A14F16 CREMES & 5000 & $3.87 \pm 0.48^{\mathrm{b}}$ & 19 & August \\
S15D16 ISAPESCA & 4000 & $3.62 \pm 0.58^{\mathrm{a}}$ & 17 & September \\
S16A17 CREMES & 5000 & $3.81 \pm 0.39^{\mathrm{b}}$ & 12 & September \\
\hline
\end{tabular}

light microscope. The gonad preparations were assigned a development stage using categories previously reported for Crassostrea corteziensis (Cuevas-Guevara \& Martínez-Guerrero, 1979; Baqueiro et al., 1992; Chávez-Villalba et al., 2008) as follows for female/male, respectively: previtellogenesis/early gametogenesis, vitellogenesis/late gametogenesis, mature, spawning, post-spawning, and repose or undifferentiated. Monthly variations in the sex ratio were determined by examining the slides under an optical microscope (40x).

\section{Statistical analyses}

All data were analyzed separately for each cultivation cycle, and only the initial oyster size was compared between the four culture cycles. Normality and homoscedasticity were confirmed using the Lilliefors' and Bartlett's tests (Sokal \& Rohlf, 1995). ANOVA was used to assess the environmental parameters. Kruskal-Wallis and post-hoc Mann-Whitney-Wilcoxon tests were used to detect differences in oyster biometrics, survival, and CI. Percentage data were first subjected to arcsine transformation before the statistical analyses. The correlations between water temperature, Chl- $a$, and spawning were assessed for each rearing cycle. Sex ratio differences were tested using Chisquare tests $\left(x^{2}\right)$ with Yates' continuity correction (Bhujel, 2008). The significant level was set up at $P \leq$ 0.05 , and Statgraphics Centurion for Windows (ver. 16) was used to perform all statistical analyses.

\section{RESULTS}

No differences $(P>0.05)$ were found in the environmental parameters among the cultivation cycles in the La Piedra Estuary, Sinaloa, Mexico (Table 2). The mean values for the four cultivation cycles were: temperature $26.5 \pm 3.7^{\circ} \mathrm{C}$, DO $5.6 \pm 0.9 \mathrm{mg} \mathrm{L}^{-1}$, salinity $32.4 \pm 1.9, \mathrm{pH} 7.6 \pm 0.3$, depth $1.5 \pm 0.3 \mathrm{~m}$, transparency
$0.6 \pm 0.2 \mathrm{~m}$, TSS $39.6 \pm 13.3 \mathrm{mg} \mathrm{L}^{-1}$, POM $10.2 \pm 3.3$ $\mathrm{mg} \mathrm{L}{ }^{-1}$, and Chl- $a 5.9 \pm 3.4 \mathrm{mg} \mathrm{m}^{3}$.

There were differences $(\mathrm{F}=9.44, P>0.0001)$ in the initial oyster size of the four culture cycles (Table 1), but the final growth and CI of Crassostrea corteziensis were not significantly different $(P \leq 0.05)$ for each cultivation cycle (Table 3$)$. The highest shell height $(80$ $\mathrm{mm})$ and the greatest total weight $(55.4 \mathrm{~g})$ were recorded for the N4J5 cultivation cycle. The mean CI was 34.2. Survival ranged from $95 \%$ obtained for the N4J5 group to 64\% from S16A17 and was significantly different for the S16A17 growth cycle $(P=0.03)$.

Six gonadal development stages were distinguished for cultivation cycles N4J5 and A14F16 (repose/ undifferentiated, previtellogenesis/early gametogenesis, vitellogenesis/late vitellogenesis, mature, spawning, and post-spawning) (Table 4). At the same time, five were observed for S15D16 (undifferentiated, gametogenesis, mature, spawning, and post-spawning) and S16A17 (undifferentiated, early gametogenesis, late gametogenesis, mature, and spawning) (Table 5).

The phases of reproduction of C. corteziensis cultivated in La Piedra estuary, Sinaloa, Mexico, at different single culture cycles indicate that spawning was recorded from February (S16A17) to October (A14F16) (Fig. 1). The frequencies of the gonadal development phases for the four farming cycles are shown Fig. 2. All N4J5 individuals were undifferentiated during the first three months. Late gametogenesis was observed from the fourth month (February 2005) onward. Maturation, spawning and post-spawning stages coincided during the last two months. By May and June, approximately $20 \%$ of the oysters were in spawning condition (Fig. 2a). Oysters were harvested in July 2005. Spawning and temperature were correlated $(\mathrm{r}=0.81, P=0.01)$. In this cultivation cycle, $4 \%$ were hermaphroditic oysters.

The gametogenic development of $C$. corteziensis in the A14F16 cycle started in February 2015 (Fig. 2b) 
Table 2. Mean \pm standard deviation, minimum, and maximum limits of the environmental parameters at La Piedra Estuary, Sinaloa, Mexico, for the four single cultivation cycles. N4J5: November 2004-June 2005, A14F16: August 2014-February 2016, S15D16: September 2015-December 2016, S16A17: September 2016-August 2017. ND: undetermined. Minimum and maximum limits are indicated in parentheses.

\begin{tabular}{lcccc}
\hline & N4J5 & A14F16 & S15D16 & S16A17 \\
\hline Temperature $\left({ }^{\circ} \mathrm{C}\right)$ & $25.5 \pm 4.7$ & $27.2 \pm 0.4$ & $26.0 \pm 4.7$ & $27.5 \pm 5.1$ \\
& $(19.0-32.0)$ & $(18.8-33.0)$ & $(19.1-32.2)$ & $(20.0-33.3)$ \\
Dissolved oxygen $\left(\mathrm{mg} \mathrm{L}^{-1}\right)$ & $6.3 \pm 1.6$ & $5.2 \pm 0.5$ & $5.3 \pm 0.8$ & $5.8 \pm 1.0$ \\
& $(5.1-7.8)$ & $(3.8-6.4)$ & $(4.1-6.4)$ & $(5.1-7.5)$ \\
Salinity & $32.1 \pm 2.2$ & $31.3 \pm 0.7$ & $32.8 \pm 2.7$ & $33.6 \pm 2.2$ \\
& $(28.0-34.8)$ & $(24.5-38.5)$ & $(28.0-38.0)$ & $(30.0-37.0)$ \\
$\mathrm{pH}$ & $8.3 \pm 0.2$ & $7.7 \pm 0.2$ & $7.4 \pm 0.2$ & $7.1 \pm 0.9$ \\
& $(8.1-8.6)$ & $(7.1-8.6)$ & $(7.1-7.9)$ & $(4.8-8.0)$ \\
Depth $(\mathrm{m})$ & $1.8 \pm 0.6$ & $1.4 \pm 0.0$ & $1.5 \pm 0.4$ & $1.5 \pm 0.4$ \\
& $(0.5-0.8)$ & $(0.7-2.2)$ & $(1.0-2.2)$ & $(0.9-2.0)$ \\
Transparency $(\mathrm{m})$ & $0.5 \pm 0.4$ & $0.5 \pm 0.0$ & $0.6 \pm 0.2$ & $0.7 \pm 0.3$ \\
& $(0.2-1.5)$ & $(0.2-0.9)$ & $(0.2-1.2)$ & $(0.3-1.3)$ \\
Total suspended solids $\left(\mathrm{mg} \mathrm{L}^{-1}\right)$ & $\mathrm{ND}$ & $43.0 \pm 18.3$ & $36.7 \pm 9.6$ & $39.3 \pm 12.1$ \\
& & $(23.7-83.2)$ & $(25.0-52.2)$ & $(22.7-61.6)$ \\
Particulate organic matter $\left(\mathrm{mg} \mathrm{L}^{-1}\right)$ & $\mathrm{ND}$ & $10.7 \pm 5.0$ & $9.1 \pm 2.5$ & $10.8 \pm 2.4$ \\
& & $(2.8-20.0)$ & $(6.1-13.3)$ & $(6.8-13.8)$ \\
Chlorophyll- $a\left(\mathrm{mg} \mathrm{m}^{-3}\right)$ & $\mathrm{ND}$ & $7.3 \pm 3.3$ & $4.5 \pm 3.3$ & $6.0 \pm 3.7$ \\
& & $(3.4-14.2)$ & $(1.1-13.0)$ & $(2.0-13.0)$ \\
\hline
\end{tabular}

Table 3. Mean \pm standard deviation of height, thickness, and width of the shell, total body weight, survival, and condition index of Crassostrea corteziensis farmed at La Piedra Estuary, Sinaloa, Mexico, for the four single cultivation cycles. N4J5: November 2004-June 2005, A14F16: August 2014-February 2016, S15D16: September 2015-December 2016, S16A17: September 2016-August 2017. ND: undetermined. ${ }^{1}$ Month of cultivation in reaching the maximum size. ${ }^{2}$ Minimum and maximum limits. "Different superscripts in the same raw denote significant differences $(P \leq 0.05)$.

\begin{tabular}{|c|c|c|c|c|}
\hline & N4J5 & A14F16 & S15D16 & S16A17 \\
\hline Shell height (mm) & $\begin{array}{c}70-80 \\
\left(\text { month } 8^{\text {th }}\right)^{1} \\
(P<0.001)\end{array}$ & $\begin{array}{c}73.3 \pm 9.1 \\
\left(\text { month } 17^{\text {th }}\right) \\
(P<0.001)\end{array}$ & $\begin{array}{c}71.9 \pm 7.6 \\
\left(\text { month } 11^{\text {th }}\right) \\
(P<0.001)\end{array}$ & $\begin{array}{c}61.5 \pm 11.2 \\
\left(\text { month } 11^{\text {th }}\right) \\
(P<0.001)\end{array}$ \\
\hline Shell thickness (mm) & ND & $\begin{array}{c}48.8 \pm 4.2 \\
(P<0.001)\end{array}$ & $\begin{array}{c}50.1 \pm 4.7 \\
(P<0.001)\end{array}$ & $\begin{array}{c}46.0 \pm 7.5 \\
(P<0.001)\end{array}$ \\
\hline Shell width (mm) & ND & $\begin{array}{c}25.6 \pm 3.3 \\
(P<0.001)\end{array}$ & $\begin{array}{c}24.4 \pm 4.1 \\
(P<0.001)\end{array}$ & $\begin{array}{c}21.4 \pm 4.5 \\
(P<0.001)\end{array}$ \\
\hline Total weight (g) & $\begin{array}{c}55.4 \pm 1.1 \\
(P<0.001)\end{array}$ & $\begin{array}{l}43.6 \pm 11.0 \\
(P<0.001)\end{array}$ & $\begin{array}{l}52.6 \pm 10.0 \\
(P<0.001)\end{array}$ & $\begin{array}{l}50.6 \pm 12.4 \\
(P<0.001)\end{array}$ \\
\hline Survival (\%) & $95.3 \pm 3.1^{\mathrm{b}^{*}}$ & ND & $94.2 \pm 1.8^{\mathrm{b}}$ & $64.6 \pm 8.5^{\mathrm{a}}$ \\
\hline $\mathrm{CI}$ & ND & $\begin{array}{c}32.6 \pm 14.8 \\
(21.5-48.6)^{2} \\
(P<0.008)\end{array}$ & $\begin{array}{c}32.2 \pm 8.0 \\
(20.4-48.7) \\
(P<0.009)\end{array}$ & $\begin{array}{c}37.9 \pm 14.5 \\
(13.9-69.5) \\
(P<0.01)\end{array}$ \\
\hline
\end{tabular}

with larger specimens (seven months-old oysters, $\sim 70$ $\mathrm{mm}$ shell height) that were sampled during 13 months of cultivation. Undifferentiated individuals were observed in autumn-winter 2016, indicating a resting phase. C. corteziensis in vitellogenesis phases (either previtellogenic or vitellogenic) were found most of the year; meanwhile, mature oysters were detected from May to September 2015. Spawning started in May and 
Table 4. Description of gonad developmental stages of Crassostrea corteziensis for the N4J5: November 2004-June 2005, and A14F16 cultivation cycles (Hemo-De ${ }^{\circledR}$ and Paraplast-Xtra ${ }^{\circledR}$, microscopic observation $40 \mathrm{X}$ ).

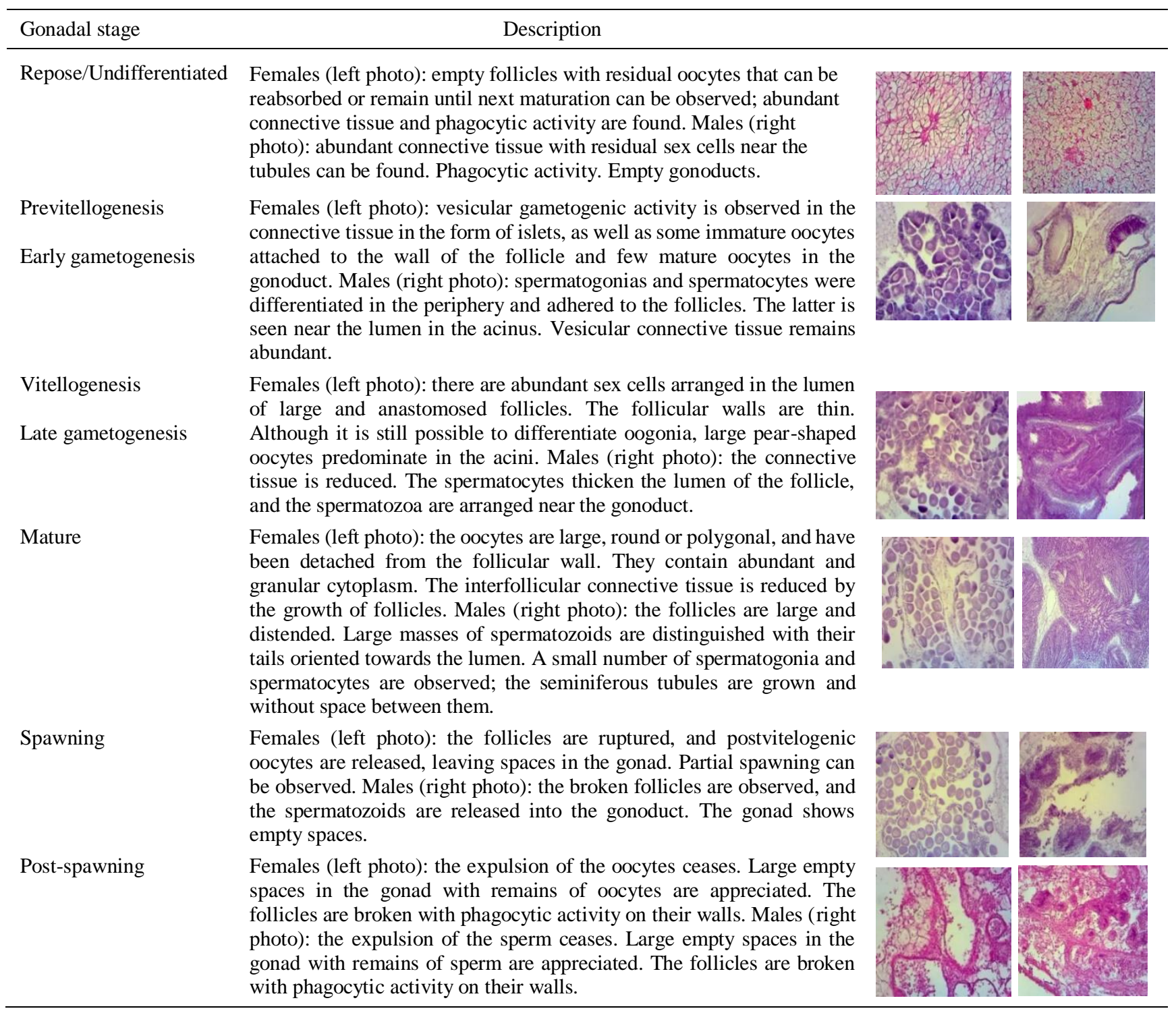

lasted six months (October) with a peak in July. Spawning was correlated with water temperature $(\mathrm{r}=$ $0.83, P<0.001)$ but not with Chl- $a(\mathrm{r}=0.11, P=0.70)$. Chl- $a$ and water temperature were not correlated $(\mathrm{r}=$ $0.31, P=0.20)$. The sex proportion (F:M = 0.75:1) was significantly different from the expected ratio $\left(x^{2}=\right.$ $133.45, \mathrm{df}=9, P<0.001)$. In this cultivation cycle, no hermaphrodite specimens were identified.

For the S15D16 farming cycle (Fig. 2c), oysters were in gametogenesis from the second sampling month (September 2015) onward, and this gonadal stage was continuously present until April 2016. Then, gonadal maturation was observed in March and April. Spawned specimens were detected from April to
November, but a reproductive peak occurred in AprilMay. Gonadal development from June to December was characterized by at least $20 \%$ post-spawned oysters. Except for April 2015, undifferentiated individuals were observed in all sampling months. In this case, spawning was not correlated with water temperature nor Chl $-a(\mathrm{r}=0.42, P=0.09$ and $\mathrm{r}=0.06$, $P=0.82$, respectively). There was no correlation between Chl- $a$ and water temperature $(\mathrm{r}=0.08, P=$ 0.76 ). In this farming, the observed sex ratio ( $\mathrm{F}: \mathrm{M}=$ $1: 1.42)$ was significantly different from the expected proportion $\left(x^{2}=123.32\right.$, $\left.\mathrm{df}=15, P<0.001\right)$. The gonads of $2.5 \%$ of the oysters analyzed displayed both oocyte and sperm cells. 
Table 5. Description of gonad developmental stages of Crassostrea corteziensis for the S15D16: September 2015December 2016, and S16A17: September 2016-August 2017 cultivation cycles (Hemo-De ${ }^{\circledR}$ and Paraplast-Xtra ${ }^{\circledR}$, microscopic observation 10x, and 40x).

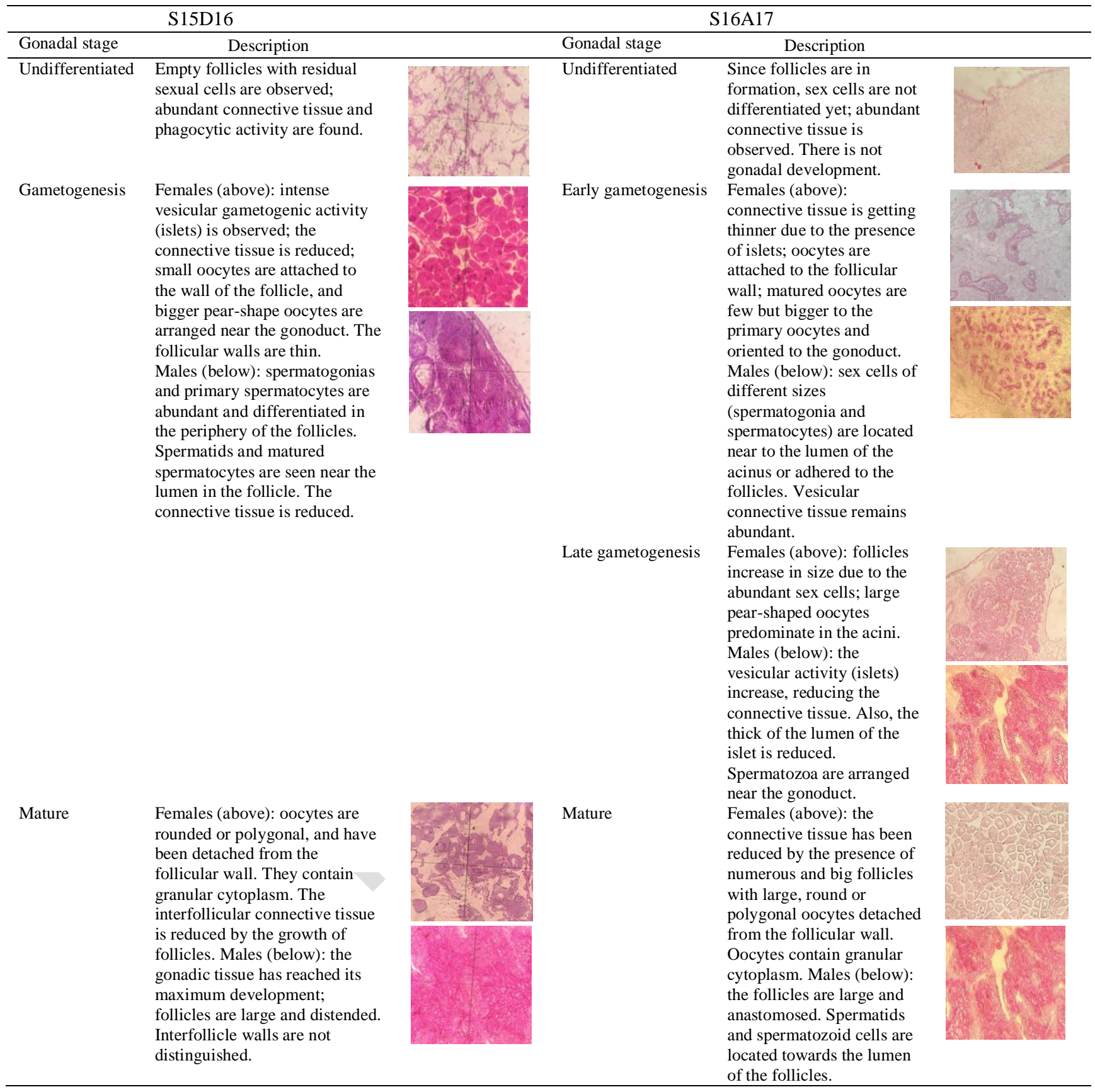


continuation

\begin{tabular}{|c|c|c|c|c|c|}
\hline \multicolumn{2}{|r|}{ S15D16 } & \multicolumn{4}{|c|}{ S16A17 } \\
\hline Gonadal stage & Description & & Gonadal stage & Description & \\
\hline Spawning & $\begin{array}{l}\text { Females (above): empty spaces } \\
\text { within the gonad indicate that } \\
\text { follicles are ruptured, and } \\
\text { oocytes were released. Partial } \\
\text { spawning was observed. } \\
\text { Males (below): broken } \\
\text { connective tissue is } \\
\text { distinguished since sex cells } \\
\text { were released to the gonoduct. }\end{array}$ & 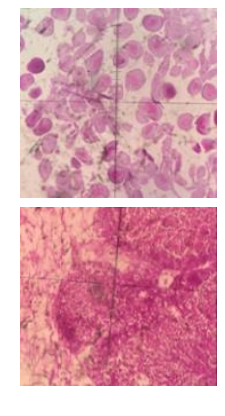 & Spawning & $\begin{array}{l}\text { Females (above): the } \\
\text { number of oocytes was } \\
\text { reduced by spawning. The } \\
\text { connective tissue and } \\
\text { follicles are ruptured. } \\
\text { Spaces in the gonad are } \\
\text { observed. Males (below): } \\
\text { follicles are broken, and } \\
\text { spaces are denoted within } \\
\text { the gonad. Sex cells are } \\
\text { released, but few } \\
\text { spermatozoids remain in } \\
\text { the follicles. }\end{array}$ & 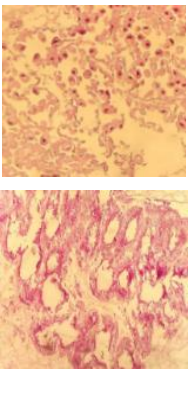 \\
\hline Post-spawning & $\begin{array}{l}\text { Females (above): residual } \\
\text { tissues and degraded cells can } \\
\text { be observed; phagocytes are } \\
\text { found in the follicles; the } \\
\text { connective tissue increases. } \\
\text { Males (below): the connective } \\
\text { tissue grows again, and the } \\
\text { gonadic tissue is degraded. } \\
\text { Residual sex cells are found in } \\
\text { the broken follicles where the } \\
\text { phagocytic activity is observed } \\
\text { on their walls. }\end{array}$ & & & & \\
\hline
\end{tabular}

The S16A17 cultivation cycle presented at least two gonadal developmental stages in each month (Fig. 2d). The first sampling month (September 2016) showed oysters in undifferentiated, early gametogenesis, late gametogenesis, and mature phases. Few spawned specimens $(10 \%)$ were registered in October, but the release of gametes occurred from January to August 2017, with more than $50 \%$ of spawned oysters observed in May-June. Similar to the S15D16 growing cycle, no correlation was found between spawning and water temperature $(\mathrm{r}=0.35, P=0.26)$, spawning and Chl- $a(\mathrm{r}$ $=0.47, P=0.12)$, and Chl $a$ and water temperature $(\mathrm{r}=$ $0.51, P=0.08)$. There were more females than males (F:M $=1.75: 1)$ throughout the samplings $\left(x^{2}=86.26\right.$, $\mathrm{df}=11, P<0.001)$. The histological analysis of gonads revealed that $2 \%$ of oysters from this growing cycle were hermaphrodites.

\section{DISCUSSION}

The reproductive strategy in natural and cultivated populations of bivalves is strongly determined by the specific environmental variables at latitudes they inhabit (Aldana-Aranda et al., 2003; Enríquez-Díaz et al., 2009). However, the reproductive tactics of any species can change because its geographic distribution covers a wide range, as is the case of bivalves that live in temperate (Ángel-Dapa et al., 2015) and sub-tropical zones (Rodríguez-Jaramillo et al., 2017), or due to environmental changes in the region caused by climatic phenomena (García-Domínguez et al., 2011).

In this study, the capacity and production availability of oyster seed of each laboratory strongly determined the seeding month, but as routinely in the region to avoid exposure of juveniles at high temperature (Rodríguez-Quiroz et al., 2016), seeding in the four cultivation cycles was done after summer (August to November). Although the oysters in this study exhibited the typical reproductive phases, there were significant differences in the reproduction intensity and the timing of the onset of gonadal development, which is in agreement with results reported by Chávez-Villalba et al. (2003) and Enríquez-Díaz et al. (2009) growing Crassostrea gigas in several marine areas of France. In the present study, the spawning of $C$. corteziensis cultivated in the southeastern Gulf of California began between January (S16A17) and May (N4J5). Chávez-Villalba et al. (2008) and Mazón-Suástegui et al. (2011) observed the first spawning in April and August, respectively, in cultivations located at latitudes farther north in the Gulf of California. Barber \& Blake (2006) mention that, in particular, water temperature and nutrients are the variables exerting the strongest influence on mollusk reproduction. The range of water temperature reported by Chávez-Villalba et al. (2008) of $15-33^{\circ} \mathrm{C}$, is wider 


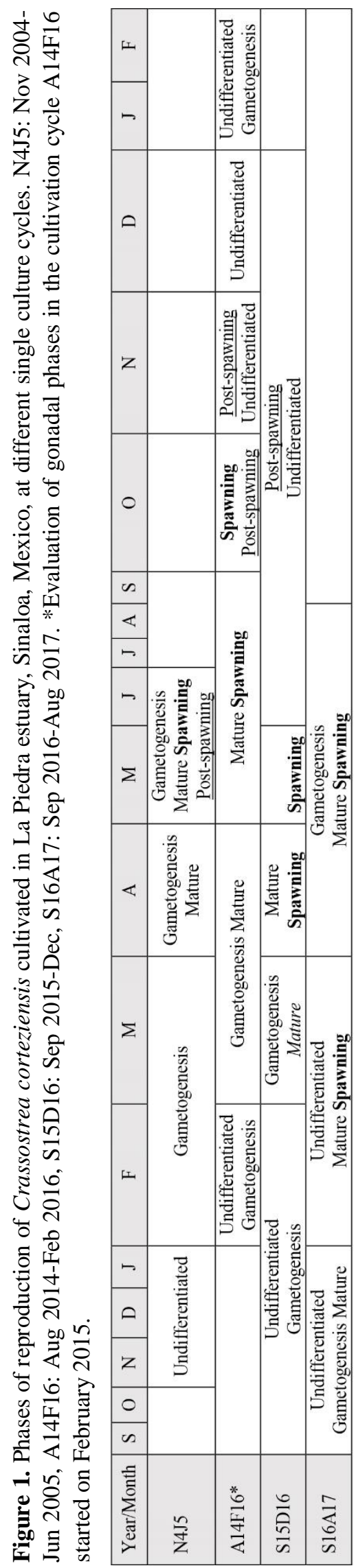

than that recorded by Mazón-Suástegui et al. (2011) $\left(22.4-32.2^{\circ} \mathrm{C}\right)$ as well as for the cultivation cycles in our study $\left(18.8-33.3^{\circ} \mathrm{C}\right)$. Duprat-Bertazzi \& GarcíaDomínguez (2005), Enríquez-Díaz et al. (2009) and Aldana-Aranda et al. (2014) note that spawning in different species of oysters (the rock oyster Hyotissa hyotis, the Japanese oyster $C$. gigas, and the eastern oyster $C$. virginica, respectively) are associated with high water temperatures, in agreement with conclusions presented by Mazón-Suástegui et al. (2011) but differs from the results reported by Chávez-Villalba et al. (2008) and the cultivation cycles reported here. In our study, spawning was registered for the first time during the months when the water temperature was increasing, and reproductive peaks were observed during different summer months (A14F16 in July, S15D16 in May and S16A17 in June) (Table 6).

The temperature data obtained were compared with the National Oceanic and Atmospheric Administration (NOAA) database to assess the presence of positive (El Niño Southern Oscillation, ENSO) or negative (La Niña weather phenomena) anomalies during the productive cycles that might influence $C$. corteziensis gonadal development. According to the values of the Oceanic Niño Index (ONI), a weak ENSO was registered from November 2014 to May 2016 followed by two normal months (June and July); then, a lowintensity La Niña of the low episode occurred from August to December 2016 (CPC, 2018). The reproductive process of the pleasure oyster between 2014 and 2017 presented a distinct seasonal pattern with maximum spawning peaks in May and June. However, the spawning intensity was lower when the La Niña phenomenon occurred; that is, during the S16A17 culture cycle, indicating that low water temperatures at the beginning of spawning could delay the reproductive activity of the pleasure oyster, as also concluded by Magaña-Carrasco et al. (2018) for $C$. virginica.

During the three most extended cultivation cycles, the Chl- $a$ concentration ranged from 1.1 to $14.2 \mathrm{mg} \mathrm{m}^{-3}$. However, it did not show a typical seasonal pattern. This range was lower than that reported by ChávezVillalba et al. (2008) ( 0-28.5 $\left.\mathrm{mg} \mathrm{m}^{-3}\right)$ at latitudes north of our cultivation site, but similar to that recorded by Rodríguez-Jaramillo et al. (2008) ( 1-15 $\left.\mathrm{mg} \mathrm{m}^{-3}\right)$ in the lagoon system in Ceuta, Sinaloa. In the S16A17 cycle, the Chl- $a$ peak was observed before spawning. Meanwhile, the highest Chl- $a$ was obtained during spawning for A14F16, and four months after spawning for S15D16. Besides, the higher Chl- $a$ values did not coincide with the summer of each year, in contrast to the results reported by Chávez-Villalba et al. (2008). It is characteristic of some species of mollusks that before 

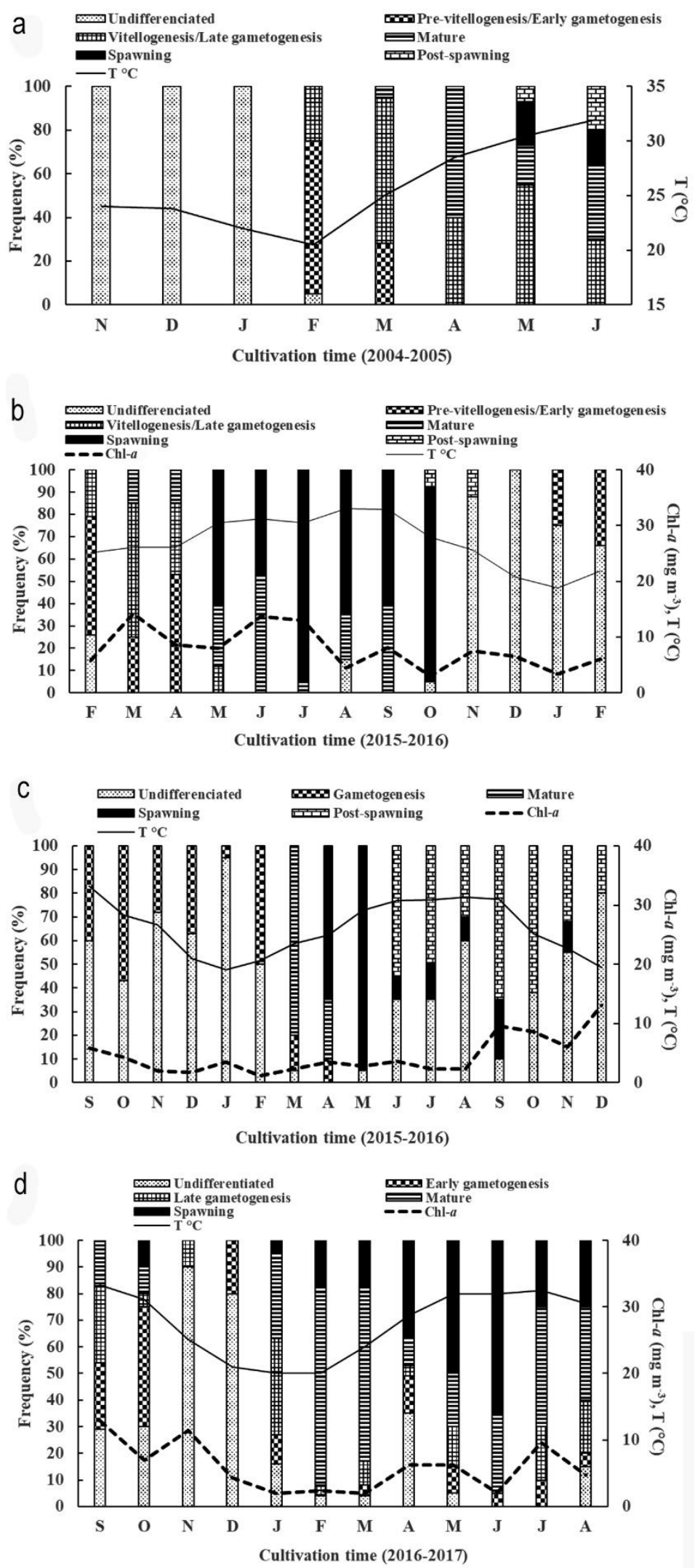

Figure 2. Frequency of the gonadic developmental stages of Crassostrea corteziensis cultivated in La Piedra Estuary, Sinaloa, Mexico, at different single culture cycles. a) N4J5, b) A14F16, c) S15D16, d) S16A17. N4J5 = Nov 2004-Jun 2005, A14F16 = Aug 2014-Feb 2016, S15D16 = Sep 2015-Dec, S16A17 = Sep 2016-Aug 2017. 


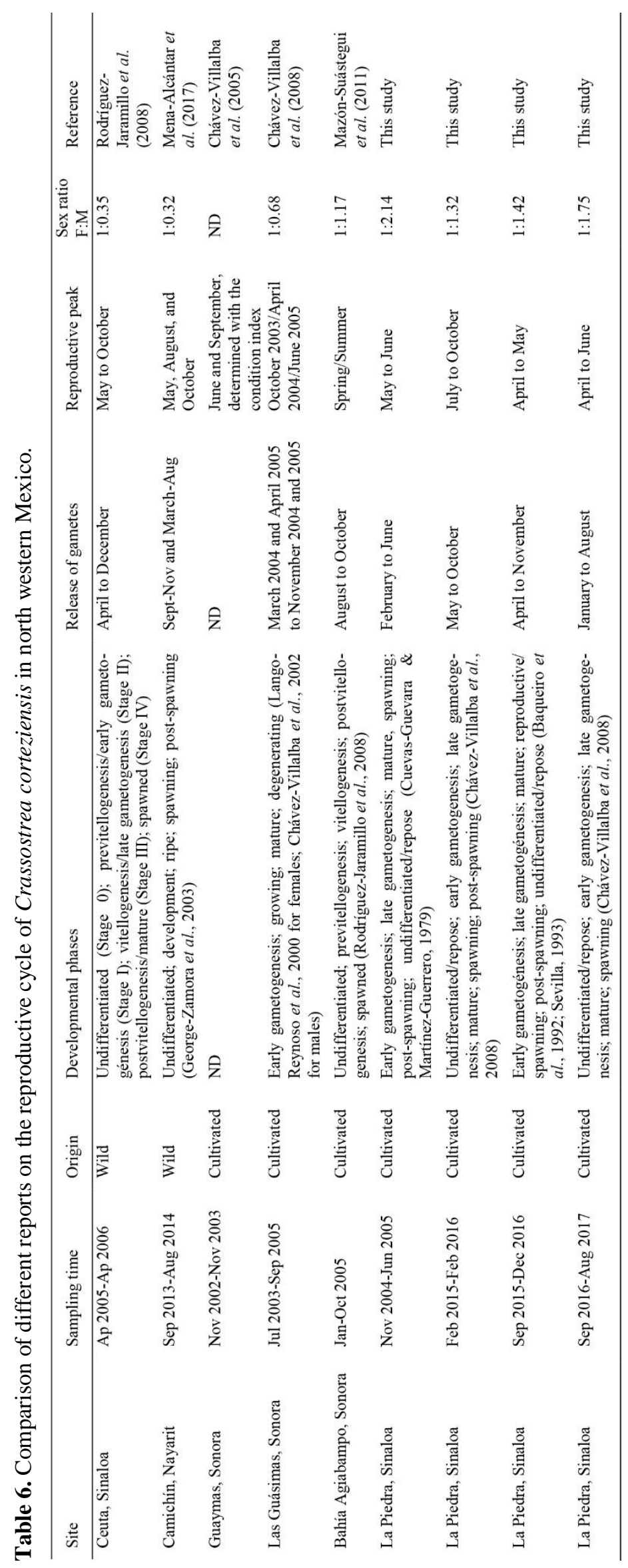


spawning, organisms store food reserve components that are used in gonadal growth and development (Rodríguez-Astudillo et al., 2005; Dridi et al., 2007; Aldana-Aranda et al., 2014), which is a distinguishing characteristic of bivalves with a conservative and seasonal reproductive strategy. In our study, $C$. corteziensis spawning evaluated from 2014 to 2017 was detected between six to nine months per year and no correlated with the Chl- $a$, indicating an opportunistic breeding strategy; this coincides with observations made by Rodríguez-Jaramillo et al. (2008) and MenaAlcántar et al. (2017) for the same species.

On the other hand, it is important to consider not only the quantity but also the quality of nutrients. As for filtering organisms, oysters ingest phytoplankton (Hurtado et al., 2012) and seston not related to chlorophyll (particles rich in organic matter) (ChávezVillalba et al., 2005). The nutritional variety provided by these inputs fulfills all of the pleasure oyster's metabolic requirements (reproduction, growth). Differences in food availability and quality during our farming cycles compared with those reported in other studies could explain the variation in the results during the gametogenic cycle. The other physical, chemical and biological parameters presented adequate ranges for oyster cultivation in the region (RodríguezJaramillo et al., 2008; Chávez-Villalba, 2014).

Oyster seed used in the four cultivation cycles were produced under controlled conditions at each laboratory (CREMES, CIBNOR, ISAPESCA), which imply broodstock management and food production (microalgae), among other standard technological procedures (Ramos et al., 2013). Nevertheless, some specific aspects not available for the farmers (broodstock origin and genetics, microalgae species and concentrations, culture conditions) may have been different among them varying seed quality also. The similar results obtained in the four cultivation cycles suggest that the growth and reproductive performance of $C$. corteziensis were not affected by the seed produced in the different laboratories.

The effect of different initial size grades of oysters on final growth and size is well documented (Foltz \& Chatry, 1986; Mason et al., 1998). For instance, Hand et al. (1999) concluded that the initial size grade of diploid and triploid rock oyster Saccostrea commercialis had a significant effect on final mean whole weight and shell height for both ploidy types, which does not match the present study. Although significant differences were found between the initial sizes of $C$. corteziensis in the four culture cycles, the final size and weight of oysters were similar regardless of the duration of the cultivation time. Kraeuter et al. (2007) mention that the growth rate of young $C$. virginica oysters is high but substantially declines once it reaches 50-60 mm shell length. Coinciding with the observations in this study, in which small pleasure oysters grew faster during the first culture months, reproduced and finally, the growth rate declined and stabilized given similar final sizes and weights at the end of each cultivation year in La Pitahaya Estuary. Earlier studies culturing C. gigas (Rodríguez-Quiroz et al., 2016; Villanueva-Fonseca et al., 2017) and $C$. corteziensis (Góngora-Gómez et al., 2018) in the same estuary reported a similarly rapid growth rate pattern at the first culture months, suggesting that more than oyster seed size, the estuary environmental conditions strongly affect oyster growth.

The oysters in cultivation cycles N4J5, A14F16, and S15D16 had a shell height of $70-80 \mathrm{~mm}$ between the $8^{\text {th }}$ and $17^{\text {th }}$ cultivation months, which is very similar to Chávez-Villalba et al. $(2005,2008)$ report of a shell height of $71.3 \mathrm{~mm}$ at 13 months and of approximately $80 \mathrm{~mm}$ at 15 months when cultivating $C$. corteziensis in different locations in the Gulf of California. The maximum shell height in S16A17 was attained in the $11^{\text {th }}$ month $(61.5 \mathrm{~mm})$. The genetic and seed sources could partially explain the difference in growth (Gutiérrez et al., 2018); however, the oysters used in A14F16 were from the same laboratory, which suggests that environmental parameters exerted a greater influence on $C$. corteziensis growth, as suggested by Hughes et al. (2017) for C. virginica. Previously, we noted that the low water temperatures registered at the beginning of that cultivation cycle could influence the pleasure oyster's reproductive activity resulting in the lower values obtained for survival and shell height. Chávez-Villalba et al. (2005) concluded that low temperatures inhibit C. corteziensis development, which is similar to our results.

As in all bivalves, $C$. corteziensis reproduction is defined by the sequence of gonadal development phases; however, several distinct classifications systems are used to identify these phases in this species (Table 6) (Cuevas-Guevara \& Martínez-Guerrero, 1979; George-Zamora et al., 2003; Osuna, 2006). Indeed, several classifications separate the description of some gonadal phases by sex (Baqueiro et al., 1992; Sevilla, 1993; Chávez-Villalba et al., 2008). In organisms with an opportunistic reproductive strategy with partial spawning and reproduction peaks throughout the year, the determination of gonadal development stages is difficult under microscopic observation because up to five phases can be differentiated in one sampling month, as occurred with S16A17.

Sexual reversion among bivalves is related to size (Lee et al., 2012) and age (Deslous-Paoli \& Héral, 
1988). The sex change has been reported for several oyster species (Mann, 1979; Gosling, 2004), including C. corteziensis (Chávez-Villalba et al., 2008). The sex ratios observed in our four cultivation cycles showed a higher proportion of males than females, coinciding with results published by Mazón-Suástegui et al. (2011), but differ from those of Chávez-Villalba et al. (2008), Rodríguez-Jaramillo et al. (2008) and MenaAlcántar et al. (2017) for the same oyster species. Baqueiro-Cárdenas (1991) described C. corteziensis as a hermaphroditic protandric species, being the first males when they are small and females when they grow larger, which also was observed in our study. The presence of hermaphroditic oysters in three of the four cultivation cycles is a common condition reported for protandric species (Chávez-Villalba et al., 2008) like $C$. corteziensis. Lango-Reynoso et al. (2006) mention that the appearance of hermaphrodites coincides with the stage of sexual transition in $C$. gigas, that is, when they are young or small. The proportion of hermaphrodites in our rearing cycles were greater than those reported for other species of oysters such as C. rhizophorae (0.8$1.3 \%$ ) (Lenz \& Boehs, 2011) and C. virginica $(0.83 \%)$ (George-Zamora et al., 2003); indeed, the proportion of hermaphroditic $C$. corteziensis in our study exceeded that reported by other researchers for the same species (1.5\%) (Chávez-Villalba et al., 2008; Mena-Alcántar et al., 2017). These distinct results may be due to differences in age (Park et al., 2012), species (Kasaynov, 2001), genetics (Gutiérrez et al., 2018), and the specific environmental conditions (Yusa, 2007) at each locality.

Constant monitoring and evaluation of other reproductive indicators such as histochemistry (Rodríguez-Jaramillo et al., 2008) and the diameter and oocyte diameter in the different phases of $C$. corteziensis development (Lango-Reynoso et al., 2000) in culture, are recommended in order to predict their reproductive seasonality accurately; this could improve larval recruitment in a natural environment facilitating better management of the species.

Our study revealed several important aspects of $C$. corteziensis development and reproduction. First, except for the A14F16 cultivation cycle, spawning was not significantly related to water temperature or food availability (Chl- $a$ ), suggesting that these variables at La Piedra Estuary region are not limited for oyster reproduction. Second, the reproductive peaks did not coincide with the maximum water temperature; instead, as water temperature increased, $C$. corteziensis presented a continuous opportunistic reproductive strategy with spawnings several months a year. Third, when sowing in November at the La Piedra Estuary region, oysters could be harvested between March and
April, just before spawning and with the best condition index, palatability, and market price. Fourth, the spawning intensity was lower during the S16A17 culture cycle, indicating that low water temperatures at the beginning of spawning could delay oyster reproductive activity. Finally, under hatchery conditions, oyster broodstock can be induced to mature sexually and to spawn outside their natural reproductive season, so the oyster seed can be produced and sown at different times of the year, which could extend the reproductive period of cultivated $C$. corteziensis. If there are several spawning events per year, the cultivation of the species from hatchery seed could increase the production of larvae and their natural settlement in the wild for more months in a year, thus contributing to the recovery of the oyster resource in a region of Mexico, where it has been heavily exploited.

\section{ACKNOWLEDGMENTS}

The authors thanks the Instituto Politécnico Nacional for the logistic and financial support to this study by the proyects: "Ciclo reproductivo del ostión japonés Crassostrea gigas cultivado en isla Los Redos, Ensenada Pabellones, Navolato, Sinaloa" (IPN-SIP 20150088 and IPN-SIP 20160456) and "Ciclo reproductivo de la almeja chocolata Megapitaria squalida (Sowerby, 1835) en bahía Agiabampo, Ahome, Sinaloa" (IPN-SIP 20170030). Thank to Kristin Sullivan for the English edition.

\section{REFERENCES}

Aldana-Aranda, D., Baqueiro-Cárdenas, E., MartínezMorales, I., Zetina-Zarate, A. \& Brulé, T. 2003. A review of the reproductive patterns of gastropod mollusks from Mexico. Bulletin of Marine Sciences, 73: 629-641.

Aldana-Aranda, D., Enríquez-Díaz, M., Lango-Reynoso, F., Brulé, T., Montero, J. \& Baqueiro-Cárdenas, E. 2014. Reproductive strategies of the eastern oyster Crassostrea virginica (Gmelin 1791) in tropical lagoons of the Mexican Gulf of Mexico. Journal of Shellfish Research, 33(1): 145-152. doi: 10.2983/0.5. 033.0114

American Public Health Association (APHA). 1995. Standard methods for the examination of water and wastewater. American Public Health Association. Washington, D.C.

Ángel-Dapa, M.A., Arellano-Martínez, M., CeballosVázquez, B.P., Acosta-Salmón, H. \& Saucedo, P.E. 2015. Comparative analysis of the reproductive strategy of lion's paw scallop Nodipecten subnodosus in Baja California Sur, Mexico. Latin American 
Journal of Aquatic Research, 43(3): 616-620. doi: 10.3856/vol43-issue3-fulltext-25

Aníbal, J., Esteves, E. \& Rocha, C. 2011. Seasonal variations in gross biochemical composition, percent edibility, and condition index of the clam Ruditapes decussatus cultivated in the Ria Formosa (South Portugal). Journal of Shellfish Research, 30(1): 17-23. doi: 10.2983/035.030.0104

Arellano-Martínez, M., Ceballos-Vázquez, B.P., RuízVerdugo, C., Pérez de León, E., Cervantes-Duarte, R. \& Domínguez-Valdéz, P.M. 2011. Growth and reproduction of the lion's paw scallop Nodipecten subnodosus in a suspended culture system at Guerrero Negro Lagoon, Baja California Sur, Mexico. Aquaculture Research, 42: 571-582. doi: 10.1111/j. 13652109.2010.02652.x

Baqueiro-Cárdenas, E. 1991. Culture of Crassostrea corteziensis in Mexico. In: Menzel, W. (Ed.). Estuarine and marine bivalve mollusk culture. CRS Press, Boca Raton, pp. 113-118.

Baqueiro, E.A., Avilés, Q.A., Masso, R.J.A., Muciño, D.M., Rogers, N.P. \& Vélez, A.B. 1992. Manual de métodos de muestreo y evaluación de poblaciones de moluscos y otros recursos bentónicos. Instituto Nacional de la Pesca-Secretaría de Pesca, Ciudad de México.

Barber, B.J. \& Blake, N.J. 2006. Reproductive physiology. In: Shumway, S.E. \& Parsons, G.J. (Eds.). Scallops: biology, ecology, and aquaculture. Elsevier, New York, pp. 357-416.

Beukema, J.J., Dekker, R. \& Jansen, J.M. 2009. Some like it cold: populations of the tellinid bivalve Macoma balthica (L.) suffer in various ways from a warming climate. Marine Ecology Progress Series, 384: 135145. doi: 10.3354/meps07952

Bhujel, R.C. 2008. Statistics for aquaculture. WileyBlackwell, Iowa.

Chávez-Villalba, J. 2014. Cultivo de ostión Crassostrea gigas: análisis de 40 años de actividades en México. Hidrobiológica, 24: 175-190.

Chávez-Villalba, J., Hernández-Ibarra, A., López-Tapia, M.R. \& Mazón-Suástegui, J.M. 2008. Prospective culture of the Cortez oyster Crassostrea corteziensis from northwestern Mexico: growth, gametogenic activity, and condition index. Journal of Shellfish Research, 27(4): 711-720. doi: 10.2983/07308000(2008)27[711:PCOTCO]2.0.CO;2

Chávez-Villalba, J., López-Tapia, M., Mazón-Suástegui, J. \& Robles-Mungaray, M. 2005. Growth of the oyster Crassostrea corteziensis (Hertlein, 1951) in Sonora, Mexico. Aquaculture Research, 36: 1337-1344. doi: 10.1111/j1365-2019.2005.01345.x
Chávez-Villalba, J., Barret, J., Mingant, C., Cochard, J.C. \& Le Pennec, M. 2003. Influence of timing of broodstock collection on conditioning, oocyte production, and larval rearing of the oyster Crassostrea gigas (Thunberg) at six production sites in France. Journal of Shellfish Research, 22: 465-474.

Climate Prediction Center (CPC). 2018. Historical El Niño/La Niña episodes (1950-present). National Weather Service, USA. [http://www.cpc.ncep.noaa. gov/products/analysis_monitoring/ensostuff/ensoyear s.html]. Reviewed: June 10, 2019.

Cuevas-Guevara, C.A. \& Martínez-Guerrero, A. 1979. Estudio gonádico de Crassostrea corteziensis Hertlein, C. palmula Carpenter y C. iridiscens Hanley, de San Blas, Nayarit, México (Bivalvia: Ostreidae). Avances del Centro de Ciencias del Mar y Limnología, 6: 81-98.

Deslous-Paoli, J.M. \& Héral, M. 1988. Biochemical composition and energy value of Crassostrea gigas (Thunberg) cultured in the bay of Marennes-Oléron. Aquatic Living Resources, 1: 239-249.

Dridi, S., Romdhane, M.S. \& Elcafsi, M. 2007. Seasonal variation in weight and biochemical composition of the Pacific oyster, Crassostrea gigas in relation to the gametogenic cycle and environmental conditions of the Bizert lagoon, Tunisia. Aquaculture, 263: 238-248. doi: 10.1016/j.aquaculture.2006.10.028

Duprat-Bertazzi, G. \& García-Domínguez, F. 2005. Reproductive cycle of the rock oyster Hyotissa hyotis (Linné, 1758) (Griphaeidae) at the La Ballena Island, Gulf of California, Mexico. Journal of Shellfish Research, 24: 987-993. doi: 10.2983/0730-8000(2005) 24[987:RCOTRO]2.0.CO;2

Enríquez-Díaz, M., Pouvreau, S., Chávez-Villalba, J. \& Le Pennec, M. 2009. Gametogenesis, reproductive investment, and spawning behavior of the Pacific giant oyster Crassostrea gigas: evidence of an environmentdependent strategy. Aquaculture International, 17(5): 491-506. doi: 10.1007/s10499-008-9219-1

Foltz, D.W. \& Chatry, M. 1986. Genetic heterozygosity and growth rate in Louisiana oysters (Crassostrea virginica). Aquaculture, 57: 261-269. doi: 10.1016/ 0044-8486(86)90204-8

Gallo-García, M.C., García-Ulloa, M., Godínez-Siordia, D.E. \& Rivera, K. 2001. Estudio preliminar sobre el crecimiento y sobrevivencia del ostión del Pacífico Crassostrea gigas (Thunberg, 1875) en Barra de Navidad, Jalisco, México. Universidad y Ciencia, 17: 83-91.

García-Domínguez, F.A., Arellano-Martínez, M., GarcíaCuellar, J.A., López-Rocha, J., Duprat-Bertazzi, G., 
Villalejo-Fuerte, M. \& Tripp-Quezada, A. 2011. Reproductive cycle of the rock oyster, Hyotissa hyotis (Linné, 1758) (Mollusca, Bivalvia, Gryphaidae) during El Niño 1997-98 and La Niña 1998-99 events at La Ballena Island, Gulf of California, Mexico. PanAmerican Journal of Aquatic Sciences, 6(3): 222-231.

George-Zamora, A., Sevilla-Hernández, M.L. \& AldanaAranda, D. 2003. Ciclo gonádico del ostión americano Crassostrea virginica (Lamellibranchia: Ostreidae) en Mecoacán, Tabasco, México. Revista de Biología Tropical, 51(4): 109-117. [https://revistas.ucr.ac.cr/ index.php/rbt/article/view/26438/26684]. Reviewed: June 10, 2019.

Gomes, C., Silva, F.C., Lopes, G.R. \& Melo, C.M.R. 2014. The reproductive cycle of the oyster Crassostrea gasar. Brazilian Journal of Biology, 74(4): 967-976. doi: 10.1590/1519-6984.04912

Góngora-Gómez, A.M., Leal-Sepúlveda, A.L., GarcíaUlloa, M., Aragón-Noriega, E.A. \& ValenzuelaQuiñonez, W. 2018. Morphometric relationships and growth models for the oyster Crassostrea corteziensis cultivated at the southeastern coast of the Gulf of California, Mexico. Latin American Journal of Aquatic Research, 46(4): 735-743. doi: 10.3856/ vol46-issue4-fulltext-11

Gosling, E. 2004. Bivalve molluscs: biology, ecology, and culture. Blackwell Science, Oxford.

Gosling, E. 2015. Marine bivalve molluscs. Fishing News Books, Oxford, pp. 157-202.

Gutiérrez, A.P., Matika, O., Bean, T.P. \& Houston, R.D. 2018. Genomic selection for growth traits in Pacific oyster (Crassostrea gigas): potential of low-density marker panels for breeding value prediction. Frontiers in Genetics, 9: 391. doi: 10.3389/fgene.2018.00391

Guzmán-García, X., Botello, A.V., Martínez-Tabche, L. \& González-Márquez, H. 2009. Effects of heavy metals on the oyster (Crassostrea virginica) at Mandinga Lagoon, Veracruz, Mexico. Revista de Biología Tropical, 57(4): 955-962. [https://revistas. ucr.ac.cr/index.php/rbt/article/view/5439/5185]. Reviewed: June 10, 2019.

Hand, R.E., Nell, J.A., Reid, D.D., Smith, I.R. \& Maguire, G.B. 1999. Studies on triploid oysters in Australia: effect of initial size on growth of diploid and triploid Sydney rock oysters, Saccostrea commercialis (Iredale \& Roughley). Aquaculture Research, 30: 3542. doi: 10.1046/j.1365-2109.1999.00296.x

Hernández-Otero, A., Martínez-Castro, C., Vázquez, E. \& Macho, G. 2014. Reproductive cycle of Ensis magnus in the Ría de Pontevedra (NW Spain): spatial variability and fisheries management implications. Journal of Sea Research, 91: 45-57. doi: 10.1016/ j.seares.2014.04.008
Hughes, A.R., Hanley, T.C., Byers, J.E., Grabowski, J.H., Malek, J.C., Piehler, M.F. \& Kimbro, D.L. 2017. Genetic by environmental variation but no local adaptation oysters (Crassostrea virginica). Ecology and Evolution, 7: 697-709. doi: 10.1002/ece3.2614

Humason, G.L. 1979. Animal tissue techniques. W.H. Freeman, San Francisco.

Hurtado, M.A., Racotta, I.S., Arcos, F., MoralesBojórquez, E., Moal, J., Soudant, P.H. \& Palacios, E. 2012. Seasonal variations of biochemical, pigment, fatty acid, and sterol compositions in female Crassostrea corteziensis oysters in relation to the reproductive cycle. Comparative Biochemistry and Physiology Part B: Biochemical and Molecular Biology, 163: 172-183. doi: 10.1016/j.cbpb.2012. 05.011

Kasyanov, V.L. 2001. Reproductive strategy of marine bivalves and echinoderms. Science Publishers, Enfield.

Kraeuter, J.N., Ford, S. \& Cummings, M. 2007. Oyster growth analysis: a comparison of methods. Journal of Shellfish Research, 26(2): 479-491. doi: 10.2983/ 0730-8000(2007)26[479:OGAACO]2.0.CO;2

Lawrence, A.J. \& Soame, J.M. 2004. The effects of climate change on the reproduction of coastal invertebrates. Ibis, 146(1): 29-39. doi: 10.1111/j.1474919X.2004.00325.X

Lango-Reynoso, F., Chávez-Villalba, J., Cochard, J.C. \& Le Pennec, M. 2000. Oocyte size, a means to evaluate the gametogenic development of the Pacific oyster, Crassostrea gigas (Thunberg). Aquaculture, 190: 183199. doi: 10.1016/S0044-8486(00)00392-6

Lango-Reynoso, F., Chávez-Villalba, J. \& Le Pennec, M. 2006. Reproductive patterns of the Pacific oyster Crassostrea gigas in France. Invertebrate Reproduction and Development, 49(1-2): 41-50. doi: 10.1080/07924259.2006.9652192

Lee, P.S., Park, J.S., Shin, Y.K., Lee, Y.G. \& Park, J.J. 2012. Sequential hermaphroditism in Manila clam Ruditapes philippinarum (Bivalvia: Veneridae). Invertebrate Reproduction and Development, 57(3): 185-188. doi: 10.1080/07924259.2012.717109

Lenz, T. \& Boehs, G. 2011. Ciclo reproductivo del ostión de manglar Crassostrea rhizophorae (Bivalvia: Ostreidae) en la Bahía de Camamu, Bahia, Brasil. Revista de Biología Tropical, 59(1): 137-149. doi: 10.15517/rbt.v59i1.3184

Magaña-Carrasco, A., Brito-Manzano, N., GómezVázquez, A. \& Cruz-Hernández, A. 2018. Effects of temperature and salinity on inducing spawning in the eastern oyster (Crassostrea virginica) under laboratory conditions. Ecosistemas y Recursos Agropecuarios, 5(14): 239-246. doi: 10.19136/era-a5n14. 1236 
Mann, R. 1979. Some biochemical and physiological aspects of growth and gametogenesis in Crassostrea gigas and Ostrea edulis grown at sustained elevated temperatures. Journal of Marine Biology Assossiation of United Kingdom, 59: 95-110. [http://agris.fao.org/ agris-search/search.do?recordID=GB 19800486593]. Reviewed: June 10, 2019.

Mason, C.J., Reid, D.D. \& Nell, J.A. 1998. Growth characteristics of Sydney rock oysters Saccostrea commercialis in relation to size and temperature. Journal of Experimental Marine Biology and Ecology, 227: 155-168.

Mazón-Suástegui, J.M., Ruíz-García， M.C., ChávezVillalba, J., Rodríguez-Jaramillo, C. \& Saucedo, P.E. 2011. Analysis of growth and first reproduction of hatchery-reared juvenile Cortes oyster (Crassostrea corteziensis) in northwestern Mexico: proposal of a minimal fishing size. Aquaculture Research, 42: 15581568. doi: 10.1111/j.1365-2109-2010.02748.x

Mena-Alcántar, M., Zavala-Leal, O.I., Romero-Bañuelos, C.A., Ruiz-Velasco, J.M.J., Nieto-Navarro, J.T., Palacios-Salgado, D. \& Pacheco-Vega, J.M. 2017. Reproduction of Cortez oyster, Crassostrea corteziensis (Hertlein, 1951) in a growing area in the central Mexican Pacific coast. Latin American Journal of Aquatic Research, 45(2): 485-490. doi: 10.3856/vol45-issue2-fulltext-23

Osuna, D.A.G. 2006. Cultivo experimental y seguimiento de la madurez gonadal por análisis histológico del ostión de placer Crassostrea corteziensis en el estero La Piedra, Guasave, Sinaloa. Tesis de Maestría en Recursos Naturales y Medio Ambiente, Instituto Politécnico Nacional, Guasave, Sinaloa.

Park, J.J., Kim, H., Kang, S.W., An, C.M., Lee, S.H., Gye, M.C. \& Lee, J.S. 2012. Sex ratio and sex reversal in two-year-old class of oyster, Crassostrea gigas (Bivalvia: Ostreidae). Development and Reproduction, 16(4): 385-388. doi: 10.12717/DR.2012. 16.4.385

Peteiro, L.G., Wooddin, S.A., Wethey, D.S., CostasCostas, D., Martínez-Casal, A., Olabarria, C. \& Vázquez, E. 2018. Responses to salinity stress in bivalves: evidence of ontogenetic changes in energetic physiology on Cerastoderma edule. Scientific Reports, 8: 8329. doi: 10.1038/s41598-018-26706-9

Racotta, I.S., Palacios, E., Ibarra, A.M., Ramírez, J.L., Arcos, F. \& Arjona, O. 2008. Comparative biochemical composition of ploidy groups of the lion paw scallop (Nodipecten subnodosus Sowerby) supports the physiological hypothesis for the lack of advantage in triploid mollusc's growth in food-rich environments. Marine Biology, 153: 1245-1256. doi: 10.1007/s00227-007-0897-4

Received: 19 August 2019; Accepted: 24 January 2020
Ramos, C.O., Ferreira, J.F. \& de Melo, C.M.R. 2013. Maturation of native oyster Crassostrea gasar at different diets in the laboratory. Boletim do Instituto de Pesca, 39(2): 107-120.

Rodríguez-Astudillo, S., Villalejo-Fuerte, M., GarcíaDomínguez, F. \& Guerrero-Caballero, R. 2005. Biochemical composition and its relationship with the gonadal index of the black oyster Hyotissa hyotis (Linnaeus, 1758) at Espiritu Santo, Gulf of California. Journal of Shellfish Research, 24: 975-978.

Rodríguez-Jaramillo, C., Ibarra, A.M., Soudant, P. \& Palacios, E. 2017. Comparison of quantitative gonad maturation scales in a temperate oyster (Crassostrea gigas) and a sub-tropical oyster (Crassostrea corteziensis). Invertebrate Reproduction and Development, 61(3): 147-156. doi: 10.1080/07924259.2017. 1315341

Rodríguez-Jaramillo, C., Hurtado, M.A., Romero-Vivas, E., Ramírez, J.L., Manzano, M. \& Palacios, E. 2008. Gonadal development and histochemistry of the tropical oyster, Crassostrea corteziensis (Hertlein, 1951) during an annual reproductive cycle. Journal of Shellfish Research, 27(5): 1129-1141. doi: 10.2983/ 0730-8000-27.5.1129

Rodríguez-Quiroz, G., García-Ulloa, M., DomínguezOrozco, A.L., Valenzuela-Hernández, T.N., NavaPérez, E. \& Góngora-Gómez, A.M. 2016. Relación del crecimiento, condición y supervivencia del ostión del Pacífico Crassostrea gigas y las variables ambientales, cultivado en suspensión en el sistema lagunar Navachiste-Macapule, Sinaloa, México. Revista de Biología Marina y Oceanografía, 51(3): 541-551. doi: 10.4067/S0718-19572016000300006

Sevilla, H.M. 1993. Las ostras de México. Aspectos básicos para su cultivo. Limusa, Ciudad de México.

Sokal, R.R. \& Rohlf, F.J. 1995. Biometry. W.H. Freeman, New York.

Strickland, J.D. \& Parsons, T.R. 1972. A practical handbook for the seawater analysis. Bulletin of Fisheries Research Board of Canada, 167: 310 pp.

Villanueva-Fonseca, B.P., Góngora-Gómez, A.M., Muñoz-Sevilla, N.P., Domínguez-Orozco, A.L., Hernández-Sepúlveda, J.A., García-Ulloa, M. \& Ponce-Palafox, J.T. 2017. Growth and economic performance of diploid and triploid Pacific oysters Crassostrea gigas cultivated in three lagoons of the Gulf of California. Latin American Journal of Aquatic Research, 45(2): 466-480. doi: 10.3856/vol45-issue2fulltext-21

Yusa, Y. 2007. Causes of variation in sex ratio and modes of sex determination in the Molluscs -an overview. American Malacology Bulletin, 23: 89-98. doi: 10.4003/0740-2783-23.1.89 